\title{
Anthropometric and dietary survey of elderly Chinese
}

\author{
BY X. SIDE, S. MINGTANG, Z. SHUQUAN, M. ZHAOMEI, X. YINZHI, L. YUJUN, \\ W. JUN AND J. KUI \\ Institute of Hygiene and Environmental Medicine, Tianjin, China
}

(Received 5 January 1990-Accepted 11 March 1991)

\begin{abstract}
The study was conducted to provide reference values of anthropometry and dietary intakes of elderly Chinese aged $\geqslant 70$ years and to investigate differences between urban and rural groups. A total of 441 subjects comprising 260 urban elderly (126 men and 134 women) and 181 rural elderly (83 men and 98 women) participated in the anthropometric study. One hundred subjects (50 men and 50 women) from both urban and rural locations were selected randomly from the anthropometric cohort for dietary survey using the method of diet recall. For both men and women, the urban elderly had significantly higher intakes of protein, fat, calcium, iron, retinol, thiamin, riboflavin and nicotinic acid than did the rural elderly. Significant sexual differences were also observed: men had higher intakes of total energy and three macronutrients than women. Both regional and sexual differences in anthropometry (but not blood pressure) seemed to be consistent with the results of the dietary survey. Positive correlations were found between systolic blood pressure and the ratio waist:hip circumference for both men and women. As a marker of adipose tissue distribution, it seemed that this ratio was more predictive of high blood pressure than body-weight.
\end{abstract}

Elderly Chinese: Dietary survey: Anthropometry

China is the most populous country and has the largest elderly population in the world. According to the 1982 census, the number of people aged $\geqslant 60$ years was $>80$ million, representing $7.63 \%$ of the total population (Huide, 1985). With gradual improvements in living conditions and medical services, the number in this age group is still increasing at a dramatic pace. Meanwhile, their health has been undermined by the nutrition-related diseases that have become the main cause of death (Huide, 1985).

Several studies in nutrition in the aged have been conducted in China (Weifu, 1984; Manchang \& Xinsu, 1987; Xianrong et al. 1987), but these studies are largely concerned with a slightly younger age group or those following a macrobiotic diet. No study on the age group of $\geqslant 70$ years has been reported. Furthermore, in such a large country with so many nationalities, food habits vary very widely in different areas. The purpose of the present study on the free-living elderly of Tianjin municipality, north China, was to provide reference values of dietary intakes and anthropometry for this age group and to compare the urban and rural elderly.

\section{SUBJECTS AND METHODS}

The anthropometric study population comprised 260 free-living subjects aged $\geqslant 70$ years (126 men and 134 women) from an urban area and 181 similar subjects ( 83 men and 98 women) from a rural area. The study was conducted in two locations, representing urban and rural areas of Tianjin municipality. The subjects from urban locations were selected randomly from the registered elderly in six residents' committees. The rural location, 
$100 \mathrm{~km}$ north of Tianjin, is a large village with a total population of 3800 . All those aged $\geqslant 70$ years living in this village were recruited for the study. The average ages for the urban men and women were 75 (SD 4) and 76 (SD 5) respectively, and for the rural men and women $74(\mathrm{SD} 4)$ and 75 (SD 5) respectively.

One hundred subjects ( 50 men and 50 women) from both urban and rural locations were selected randomly from the anthropometric cohort for the dietary survey, which took place between May and November of 1988. The subjects gave their informed consent. Diet recall was used: the subjects were asked about their food and drink consumption during the immediately preceding $24 \mathrm{~h}$. For each subject, a total of three consecutive days were recalled, but weekends and other special occasions such as holidays, birthdays and marriage feasts were excluded. This was because no weekends and fewer holidays are taken in rural areas of China and comparisons between the urban and rural situations are thus more easily made. Common household measures were used to record the quantities of all foods. The average ages for the groups taking part in the dietary survey were 75 (SD 4) and 76 (SD 5) for urban men and women, and 75 (SD 4) and 76 (SD 5) for rural men and women respectively.

Nutrient intakes were calculated using Tables of Food Composition (Academy of Medical Science of China, 1983). Two nutritionists were appointed to supervise diet recall and the subsequent food code and nutrient analysis.

Three people carried out the anthropometric measurements throughout the entire experiment. One recorded body-weight and height, another measured triceps skinfold thickness and the circumferences of upper arm, waist and hip, and the third recorded blood pressure. Body-weight was recorded in indoor clothing, without shoes, using a portable scale, height was measured to the nearest centimetre using a $2 \mathrm{~m}$ rule taped vertically to a wall, and body mass index (BMI) was calculated as weight $(\mathrm{kg}) /$ height $(\mathrm{m})^{2}$. Upper arm circumference was taken at the mid-point between the acromion and olecranon processes, and triceps skinfold thickness was measured with callipers at the same point. Waist circumference was measured at the level of the umbilicus with the subject standing and breathing normally, and hip circumference was measured at the level of the iliac crest, both to the nearest centimetre. The ratio waist circumference: hip circumference was calculated. Blood pressure was measured to the nearest $2 \mathrm{mmHg}$ with the subject sitting after a $5 \mathrm{~min}$ interview, using a cuff with a rubber bag measuring $12 \times 23 \mathrm{~cm}$. All results are the average of two measurements.

\section{Statistical analysis}

Values were analysed by Student's $t$ test, analysis of correlation and the $\chi^{2}$ test, with $P<0.05$ being taken as statistically significant.

\section{RESULTS}

All the anthropometric indices of the urban elderly (but not blood pressure) were higher in varying degrees than those of rural elderly of the same gender (Table 1). The differences in body-weight, height, BMI, the four circumferences and triceps skinfold thickness were statistically significant. Height, body-weight, waist circumference and the ratio waist: hip circumference were significantly higher for men than women in both regions, but the reverse was true for triceps skinfold thickness. The upper arm muscle circumference was higher for men only in rural areas. No significant differences in blood pressure were found.

The ratio waist circumference: hip circumference was positively correlated with systolic blood pressure, whether or not it was associated with body-weight, or waist or hip circumference (Table 2). BMI was divided into four ranges, $<20,20 \cdot 0-23 \cdot 9,24 \cdot 0-26 \cdot 9$ and 
Table 1. Anthropometric indices for subjects from urban and rural areas of China

\begin{tabular}{|c|c|c|c|c|c|c|c|c|}
\hline & \multicolumn{4}{|c|}{ Urban } & \multicolumn{4}{|c|}{ Rural } \\
\hline & \multicolumn{2}{|c|}{$\begin{array}{c}\text { Men } \\
(n \text { 126) }\end{array}$} & \multicolumn{2}{|c|}{$\begin{array}{l}\text { Women } \\
(n \text { 134) }\end{array}$} & \multicolumn{2}{|c|}{$\begin{array}{l}\text { Men } \\
(n 83)\end{array}$} & \multicolumn{2}{|c|}{$\begin{array}{l}\text { Women } \\
(n 98)\end{array}$} \\
\hline & Mean & SD & Mean & SD & Mean & SD & Mean & SD \\
\hline Height (m) & $1 \cdot 67 * *$ & $0 \cdot 11$ & $1 \cdot 54^{*}$ & $0-06$ & $1.63^{*}$ & 0.06 & $1 \cdot 51^{* *}$ & 0.06 \\
\hline Body-weight (kg) & $65 \cdot 9 * *$ & $11 \cdot 2$ & $54 \cdot 4^{*}$ & $10 \cdot 8$ & $53 \cdot 8^{*}$ & $7 \cdot 5$ & $46 \cdot 8^{* *}$ & $8 \cdot 5$ \\
\hline Body mass index $\uparrow$ & $23 \cdot 2 * *$ & $3 \cdot 3$ & $23 \cdot 0$ & $4 \cdot 4$ & $20 \cdot 4$ & $2 \cdot 6$ & $20 \cdot 6^{* *}$ & $3 \cdot 3$ \\
\hline \multicolumn{9}{|l|}{ Blood pressure $(\mathrm{mmHg})$} \\
\hline Systolic & 141 & 25 & 145 & 22 & 141 & 20 & 147 & 22 \\
\hline Diastolic & 82 & 12 & 82 & 11 & 83 & 14 & 81 & 13 \\
\hline Waist circumference $(\mathrm{cm})$ & $88 \cdot 3 * *$ & $9 \cdot 6$ & $84.9 *$ & $11 \cdot 1$ & $77 \cdot 6$ & $6 \cdot 8$ & $75 \cdot 5^{* *}$ & 80 \\
\hline Hip circumference $(\mathrm{cm})$ & $99 \cdot 9 * *$ & $9 \cdot 4$ & $98 \cdot 4$ & $11 \cdot 2$ & $86 \cdot 4$ & $5 \cdot 3$ & $87 \cdot 2^{* *}$ & 6.5 \\
\hline Upper arm circumference $(\mathrm{cm})$ & $28 \cdot 1^{* *}$ & $7 \cdot 6$ & $26 \cdot 3 *$ & $4 \cdot 2$ & $23 \cdot 8$ & $2 \cdot 3$ & $23 \cdot 3 * *$ & $2 \cdot 7$ \\
\hline $\begin{array}{l}\text { Triceps skinfold thickness } \\
(\mathrm{mm})\end{array}$ & $14 \cdot 1^{* *}$ & $4 \cdot 1$ & $16 \cdot 7^{*}$ & $5 \cdot 8$ & $6.6^{*}$ & $3 \cdot 8$ & $11 \cdot 2 * *$ & 4.9 \\
\hline $\begin{array}{l}\text { Upper arm muscle } \\
\text { circumference }(\mathrm{cm})\end{array}$ & $23 \cdot 7^{* *}$ & $6 \cdot 7$ & $21 \cdot 0$ & $5 \cdot 7$ & $21 \cdot 7^{*}$ & $1 \cdot 8$ & $19 \cdot 8^{* *}$ & 1.9 \\
\hline Waist : hip circumference & $0 \cdot 88^{* *}$ & $0-05$ & $0 \cdot 86^{*}$ & 0.06 & $0 \cdot 90^{*}$ & $0-06$ & 0.87 & 0.05 \\
\hline
\end{tabular}

*, Significantly different from the corresponding group from the same area, $P<0.05 ;{ }^{* *}$, significantly different from the same gender group from the other area, $P<0.05$.

$\dagger$ Wt $(\mathrm{kg}) /$ height $(\mathrm{m})^{2}$.

Table 2. Correlation coefficients between systolic blood pressure and several anthropometric indices $\dagger$ for subjects from urban and rural areas of China

\begin{tabular}{|c|c|c|c|c|c|}
\hline & & \multicolumn{2}{|c|}{ Urban } & \multicolumn{2}{|c|}{ Rural } \\
\hline & & Men & Women & Men & Women \\
\hline$n$ & & 126 & 134 & 83 & 98 \\
\hline \multirow[t]{4}{*}{ Blood pressure } & v. Body-weight & 0.076 & $0.245^{* *}$ & $0-076$ & $0.269 * *$ \\
\hline & v. Waist circumference & $0 \cdot 293^{* *}$ & $0 \cdot 290^{* *}$ & $0 \cdot 161$ & $0 \cdot 312 * *$ \\
\hline & v. Hip circumference & $0 \cdot 120$ & $0 \cdot 196^{*}$ & $0 \cdot 070$ & $0.218 * *$ \\
\hline & v. Waist : hip circumference & $0.336^{* *}$ & $0 \cdot 238^{* *}$ & $0.278^{* *}$ & $0 \cdot 316^{* *}$ \\
\hline
\end{tabular}

Significant correlation: ${ }^{*}, P<0.05 ;{ }^{* *}, P<0.01$.

$\dagger$ See Table 1 for values.

$\geqslant 27$, defined as underweight, normal, overweight and fat according to the Chinese classification. In the present study, the rates of overweight plus fat for the urban elderly were respectively 41.3 and $38.1 \%$ for men and women, significantly higher than those for the rural elderly $(6 \cdot 0$ and $15.3 \%$ for men and women respectively).

The results of the dietary survey are given in Tables 3-7. In absolute terms, the urban elderly consumed more energy and macronutrients than did the rural elderly, and men consumed those more than women (Table 3). However, when energy intake was expressed per $\mathrm{kg}$ body-weight, the intake of urban males was lower than that of urban females and rural males, although the intake of rural males was still higher than that of rural females. The proportion of dietary energy derived from protein and fat was also higher in the urban elderly, but the reverse was true for carbohydrate. These differences arose mainly from their different intakes of animal foods (Tables 4 and 6). Regional differences were found in the 
Table 3. Nutrient intakes for subjects from urban and rural areas of China (Mean and SD for 50 subjects)

\begin{tabular}{|c|c|c|c|c|c|c|c|c|}
\hline & \multicolumn{4}{|c|}{ Urban } & \multicolumn{4}{|c|}{ Rural } \\
\hline & \multicolumn{2}{|c|}{ Men } & \multicolumn{2}{|c|}{ Women } & \multicolumn{2}{|c|}{ Men } & \multicolumn{2}{|c|}{ Women } \\
\hline & Mean & SD & Mean & SD & Mean & SD & Mean & SD \\
\hline Energy $(\mathrm{MJ} / \mathrm{d})$ & $8 \cdot 06$ & $1 \cdot 43$ & $7 \cdot 38^{*}$ & $1 \cdot 13$ & $7 \cdot 94^{*}$ & $1 \cdot 33$ & 6.71 & 0.89 \\
\hline$(\mathrm{MJ} / \mathrm{kg}$ body-wt $)$ & $0 \cdot 12^{* *}$ & 0.01 & $0 \cdot 14^{*}$ & 0.01 & $0 \cdot 15^{*}$ & 0.02 & $0 \cdot 14$ & 0.01 \\
\hline Protein $(\mathrm{g} / \mathrm{d})$ & $59 * *$ & 12 & $54^{*}$ & 9 & $43^{*}$ & 8 & $38^{* *}$ & 6 \\
\hline$(\%$ energy $)$ & $12 \cdot 3^{* *}$ & $2 \cdot 1$ & $12 \cdot 4$ & 1.7 & $9 \cdot 1$ & $0 \cdot 8$ & $9 \cdot 5^{* *}$ & $1 \cdot 1$ \\
\hline Fat $(g / d)$ & $65^{* *}$ & 13 & $57^{*}$ & 13 & $60^{*}$ & 12 & $50^{* *}$ & 11 \\
\hline (\% energy) & $30 \cdot 3^{* *}$ & $4 \cdot 3$ & $31 \cdot 1$ & $4 \cdot 6$ & $28 \cdot 4$ & $4 \cdot 7$ & $28 \cdot 1^{* *}$ & $4 \cdot 1$ \\
\hline Carbohydrate $(\mathrm{g} / \mathrm{d})$ & 276 & 56 & $250^{*}$ & 51 & 279 & 49 & $250^{*}$ & 43 \\
\hline$(\%$ energy $)$ & $57 \cdot 1 * *$ & $5 \cdot 1$ & $56 \cdot 4$ & $4 \cdot 7$ & $59 \cdot 8$ & $7 \cdot 0$ & $62 \cdot 3^{* *}$ & $5 \cdot 3$ \\
\hline Calcium (mg) & $439 * *$ & 194 & 370 & 138 & 292 & 93 & $254^{* *}$ & 76 \\
\hline Iron (mg) & $18 \cdot 0$ & $5 \cdot 2$ & $16 \cdot 3$ & $4 \cdot 0$ & 16.5 & $4 \cdot 2$ & $13 \cdot 6^{* *}$ & $2 \cdot 20$ \\
\hline Retinol $(\mu \mathrm{g})$ & $648 * *$ & 489 & 617 & 254 & 167 & 91 & $116^{* *}$ & 87 \\
\hline Thiamin $(\mathrm{mg} / \mathrm{d})$ & $1 \cdot 3^{* *}$ & $0 \cdot 3$ & $1 \cdot 2$ & 0.2 & $1 \cdot 2^{*}$ & 0.2 & $1 \cdot 0^{* *}$ & $0 \cdot 2$ \\
\hline$(\mathrm{mg} / \mathrm{MJ})$ & $0 \cdot 17$ & 0.02 & $0 \cdot 16$ & 0.02 & 0.15 & 0.02 & $0 \cdot 14$ & 0.02 \\
\hline Riboflavin (mg/d) & $0 \cdot 8^{* *}$ & $0 \cdot 3$ & 0.7 & $0 \cdot 2$ & 0.4 & $0 \cdot 1$ & $0 \cdot 4^{* *}$ & $0 \cdot 1$ \\
\hline$(\mathrm{mg} / \mathrm{MJ})$ & $0 \cdot 10^{* *}$ & 0.03 & $0 \cdot 10$ & 0.02 & 0.06 & 0.01 & $0.06^{* *}$ & 0.01 \\
\hline Ascorbic acid (mg) & 59 & 32 & 56 & 25 & 49 & 27 & 44 & 23 \\
\hline Nicotinic acid (mg/d) & $11 \cdot 3^{* *}$ & $3 \cdot 2$ & $9 \cdot 6$ & 1.9 & 8.8 & 1.8 & $7 \cdot 8 * *$ & 1.5 \\
\hline$(\mathrm{mg} / \mathrm{MJ})$ & $1 \cdot 40^{* *}$ & $0 \cdot 28$ & $1 \cdot 31$ & $0 \cdot 21$ & $1 \cdot 11$ & 0.18 & $\mathrm{I} \cdot 16$ & $0 \cdot 21$ \\
\hline
\end{tabular}

*, Significantly different from the corresponding group from the same area, $P<0.05$; **, significantly different from the same gender group from the other area, $P<0-05$.

Table 4. Percentage contribution of different food sources to total protein and fat intakes of subjects from urban and rural areas of China

(Mean and SD for 50 subjects)

\begin{tabular}{|c|c|c|c|c|c|c|c|c|c|c|}
\hline & \multicolumn{6}{|c|}{ Protein } & \multicolumn{4}{|c|}{ Fat } \\
\hline & \multicolumn{2}{|c|}{ Cerea! } & \multicolumn{2}{|c|}{ Bean + animal } & \multicolumn{2}{|c|}{ Others } & \multicolumn{2}{|c|}{ Plant } & \multicolumn{2}{|c|}{ Animal } \\
\hline & Mean & SD & Mean & SD & Mean & $\mathrm{SD}$ & Mean & SD & Mean & SD \\
\hline \multicolumn{11}{|l|}{ Urban } \\
\hline Men & $44 \cdot 2$ & $12 \cdot 2$ & $41 \cdot 5$ & $11 \cdot 2$ & $14 \cdot 3$ & 9.4 & $54 \cdot 7$ & 12.9 & $45 \cdot 3$ & 12.9 \\
\hline Women & $46 \cdot 6$ & $10 \cdot 6$ & $42 \cdot 7$ & $10 \cdot 2$ & $10 \cdot 7$ & $6 \cdot 2$ & 56.5 & 15.9 & $43 \cdot 5$ & 15.8 \\
\hline \multicolumn{11}{|l|}{ Rural } \\
\hline Men & $67 \cdot 0^{*}$ & $12 \cdot 6$ & $24 \cdot 2^{*}$ & $10 \cdot 2$ & $8 \cdot 8^{*}$ & $4 \cdot 6$ & $69.8^{*}$ & 14.9 & $30 \cdot 1^{*}$ & 149 \\
\hline Women & $70 \cdot 3 *$ & $9 \cdot 0$ & $22 \cdot 4^{*}$ & $9 \cdot 9$ & $7 \cdot 4^{*}$ & $3 \cdot 5$ & $71 \cdot 0^{*}$ & $11 \cdot 0$ & $29 \cdot 0^{*}$ & $12 \cdot 0$ \\
\hline
\end{tabular}

*, Significantly different from the same gender group from the other area, $P<0.05$.

intakes of calcium, retinol, thiamin, riboflavin and nicotinic acid in either absolute or relative terms. No differences were found between the sexes, probably due to the large standard deviations. Table 5 compares these results with RDA (The Chinese Nutrition Society, 1989). The intakes of energy for both men and women were equal to or slightly above the RDA in both areas. Protein intakes were close to the RDA for the urban elderly, but far below it for the rural elderly. Fat intake provided $>28 \%$ of the total dietary energy, exceeding the RDA of $20-25 \%$. When compared with the RDA, intakes of 
Table 5. Actual intake of subjects from urban and rural areas expressed as \% RDA (The Chinese Nutrition Society, 1990) for those aged $\geqslant 70$ years

\begin{tabular}{|c|c|c|c|c|c|}
\hline & \multirow[b]{2}{*}{$\mathrm{RDA}$} & \multicolumn{2}{|c|}{ Urban } & \multicolumn{2}{|c|}{ Rural } \\
\hline & & Intake & $\%$ RDA & Intake & $\% \mathrm{RDA}$ \\
\hline \multicolumn{6}{|l|}{ Men } \\
\hline Energy (MJ) & $7 \cdot 53$ & 8.06 & 107 & 7.94 & 105 \\
\hline Protein (g) & 65 & 59 & 91 & 43 & 67 \\
\hline Fat $(\%$ energy $)$ & $20-25$ & 65 & 30 & 60 & 28 \\
\hline Calcium (mg) & 800 & 439 & 55 & 292 & 36 \\
\hline Iron $(\mathrm{mg})$ & 12 & $18 \cdot 0$ & 150 & 16.5 & 138 \\
\hline Retinol $(\mu \mathrm{g})$ & 800 & 648 & 81 & 167 & 21 \\
\hline Thiamin (mg) & 1.2 & $1 \cdot 3$ & 111 & 1.2 & 96 \\
\hline Riboflavin (mg) & $1 \cdot 2$ & 0.8 & 68 & 0.5 & 38 \\
\hline Ascorbic acid (mg) & 60 & 59 & 98 & 49 & 82 \\
\hline Nicotinic acid (mg) & 12 & $11 \cdot 3$ & 94 & $8 \cdot 8$ & 73 \\
\hline \multicolumn{6}{|l|}{ Women } \\
\hline Energy (MJ) & $6 \cdot 70$ & $7 \cdot 38$ & 110 & $6 \cdot 7$ & 100 \\
\hline Protein $(\mathrm{g})$ & 55 & 54 & 99 & 38 & 69 \\
\hline Fat (\% energy) & $20-25$ & 57 & 31 & 50 & 28 \\
\hline Calcium (mg) & 800 & 370 & 46 & 255 & 32 \\
\hline Iron (mg) & 12 & $16 \cdot 3$ & 135 & 13.6 & 113 \\
\hline Retinol $(\mu \mathrm{g})$ & 800 & 617 & 77 & 116 & 15 \\
\hline Thiamin $(\mathrm{mg})$ & $1 \cdot 2$ & $1 \cdot 2$ & 100 & $1 \cdot 0$ & 83 \\
\hline Riboflavin (mg) & $1 \cdot 2$ & 0.7 & 60 & 0.4 & 33 \\
\hline Ascorbic acid (mg) & 60 & $55 \cdot 6$ & 93 & $43 \cdot 9$ & 73 \\
\hline Nicotinic acid (mg) & 12 & $9 \cdot 6$ & 80 & 7.8 & 65 \\
\hline
\end{tabular}

Table 6. Intake $(\mathrm{g})$ of different foods by subjects from urban and rural areas of China (Mean and SD for 50 subjects)

\begin{tabular}{|c|c|c|c|c|c|c|c|c|}
\hline \multirow[b]{3}{*}{ Food } & \multicolumn{4}{|c|}{ Urban } & \multicolumn{4}{|c|}{ Rural } \\
\hline & \multicolumn{2}{|c|}{ Men } & \multicolumn{2}{|c|}{ Women } & \multicolumn{2}{|c|}{ Men } & \multicolumn{2}{|c|}{ Women } \\
\hline & Mean & $\mathrm{SD}$ & Mean & SD & Mean & $\mathrm{SD}$ & Mean & SD \\
\hline Total & $1015^{* *}$ & 367 & 1006 & 286 & $709^{*}$ & 142 & $604^{* *}$ & 94 \\
\hline Cereals & $319 * *$ & 81 & 313 & 60 & $357^{*}$ & 56 & $317^{* *}$ & 55 \\
\hline Bean products & $168^{* *}$ & 104 & 203 & 141 & $20^{*}$ & 10 & $13^{* *}$ & 9 \\
\hline Vegetables & 192 & 62 & 171 & 82 & 218 & 101 & 184 & 85 \\
\hline Meat (ME) & $42^{* *}$ & 26 & 32 & 17 & $26^{*}$ & 12 & $24^{* *}$ & 10 \\
\hline Eggs (EG) & $44^{* *}$ & 19 & 50 & 21 & $17^{*}$ & 8 & $14^{* *}$ & 5 \\
\hline Milk (MI) & $102^{* *}$ & 76 & 76 & 53 & $5 *$ & 1 & $3 * *$ & 1 \\
\hline Fish $(\mathrm{Fl})$ & $19^{* *}$ & 10 & 20 & 12 & $13^{*}$ & 3 & $7^{* *}$ & 3 \\
\hline $\mathrm{ME}+\mathrm{EG}+\mathrm{MI}+\mathrm{FI}$ & $207^{* *}$ & 34 & $173^{*}$ & 28 & $61^{*}$ & 7 & $48^{* *}$ & 5 \\
\hline Fruit & $90^{* *}$ & 56 & 105 & 74 & $11^{*}$ & 4 & $8^{* *}$ & 2 \\
\hline Plant oil & 23 & 6 & 21 & 8 & 23 & 7 & 20 & 5 \\
\hline Lard & 3 & 2 & 4 & 2 & $7^{*}$ & 3 & 5 & 3 \\
\hline Salt & 12 & 3 & 11 & 2 & 12 & 2 & 11 & 2 \\
\hline
\end{tabular}

*, Significantly different from the corresponding group from the same area, $P<0.05$; **, significantly different from the same gender group from the other area, $P<0.05$. 
Table 7. Percentage contribution of different foods to total energy intake of subjects from urban and rural areas of China

(Mean and SD for 50 subjects)

\begin{tabular}{|c|c|c|c|c|c|c|c|c|}
\hline \multirow[b]{3}{*}{ Food } & \multicolumn{4}{|c|}{ Urban } & \multicolumn{4}{|c|}{ Rural } \\
\hline & \multicolumn{2}{|c|}{ Men } & \multicolumn{2}{|c|}{ Women } & \multicolumn{2}{|c|}{ Men } & \multicolumn{2}{|c|}{ Women } \\
\hline & Mean & SD & Mean & SD & Mean & SD & Mean & SD \\
\hline Cereals & $57 \cdot 8^{* *}$ & 8.7 & $58 \cdot 5$ & $7 \cdot 8$ & $65 \cdot 6$ & $8 \cdot 7$ & $67 \cdot 4^{* *}$ & $6 \cdot 9$ \\
\hline Bean products & $5 \cdot 8 * *$ & $2 \cdot 9$ & 6.5 & $3 \cdot 0$ & $2 \cdot 5$ & 1.6 & $2 \cdot 6 * *$ & $1 \cdot 1$ \\
\hline Vegetables & $2 \cdot 7^{* *}$ & $0 \cdot 8$ & $2 \cdot 6$ & 1.4 & $4 \cdot 0$ & $2 \cdot 4$ & $3 \cdot 6^{* *}$ & $2 \cdot 8$ \\
\hline Meat $(\mathrm{ME})$ & $10 \cdot 6^{* *}$ & $4 \cdot 3$ & 9.9 & 4.5 & 79 & $4 \cdot 6$ & $8 \cdot 0^{* *}$ & 40 \\
\hline Eggs (EG) & $4 \cdot 0^{* *}$ & $1 \cdot 8$ & $5 \cdot 1^{*}$ & $2 \cdot 6$ & $1.5^{*}$ & 0.9 & $0.9^{* *}$ & $0 \cdot 6$ \\
\hline Milk (MI) & $3 \cdot 7^{* *}$ & $2 \cdot 8$ & $1.9^{*}$ & $1 \cdot 4$ & $2 \cdot 8^{*}$ & 0.7 & $0 \cdot 9^{* *}$ & $0 \cdot 4$ \\
\hline Fish (FI) & $1 \cdot 3$ & $0 \cdot 7$ & $0.9^{*}$ & 0.5 & $1 \cdot 3^{*}$ & $0 \cdot 7$ & $0 \cdot 5^{* *}$ & $0 \cdot 3$ \\
\hline $\mathrm{ME}+\mathrm{EG}+\mathrm{MI}+\mathrm{FI}$ & $19 \cdot 6^{* *}$ & $2 \cdot 6$ & $19 \cdot 9$ & 40 & $13 \cdot 5^{*}$ & $2-3$ & $10 \cdot 2^{* *}$ & 1.6 \\
\hline Fruit & $1.9 * *$ & $1 \cdot 2$ & 1.6 & $1 \cdot 2$ & 0.3 & $0 \cdot 2$ & $0 \cdot 3 * *$ & 0.17 \\
\hline Plant oil & $10 \cdot 6$ & $3 \cdot 6$ & $10 \cdot 9$ & $3 \cdot 4$ & $11 \cdot 1$ & $4 \cdot 1$ & $11 \cdot 6$ & $4 \cdot 8$ \\
\hline Lard & $1 \cdot 4 * *$ & $0 \cdot 2$ & $2 \cdot 0^{*}$ & $0 \cdot 2$ & $3 \cdot 1$ & $0 \cdot 3$ & $2 \cdot 9 * *$ & $0 \cdot 3$ \\
\hline
\end{tabular}

*, Significantly different from the corresponding group from the same area, $P<0.05 ;{ }^{* *}$, significantly different from the same gender group from the other area, $P<0.05$.

calcium, retinol, riboflavin and ascorbic acid were rather low, especially in the rural elderly. Tables 6 and 7 show the mean intakes of various foods and their contributions to total energy. Alcohol was not listed, since only a few of the subjects $(21 \%$ of the men and $3.6 \%$ of the women) reported that they still consumed alcohol, and then only occasionally and in very small quantities. Urban groups had significantly higher consumptions of animal foods and fruits than the rural groups. Meat, eggs, milk and fish provided $19 \cdot 6$ and $19.9 \%$ of the total dietary energy for urban men and women respectively, but only 13.5 and $10.2 \%$ of total energy for the corresponding rural groups. The great differences in consumption of milk and bean products between the two areas resulted from their different dietary habits: urban dwellers generally drink fresh milk or soya-bean milk while rural people consume milk powder and bean curd.

\section{DISCUSSION}

The present paper reports the results of anthropometry and dietary survey on both urban and rural groups of the Tianjin elderly aged $\geqslant 70$ years. Previous reports on the elderly (Weifu, 1984; Manchang \& Xinsu, 1987; Xianrong et al. 1987) have concentrated on rather different groups. Thus, even though our sample was relatively small, our results are the first to provide reference values of nutrient intakes and anthropometry for this age group

\section{Dietary survey}

In absolute terms, the intakes of energy and three macronutrients were found to be significantly higher for men than women. The same trend was also observed with other nutrients, but differences were not significant. These differences arose partly from the men's higher intake of animal foods, since they are traditionally privileged in the division of animal foods within the family. It was also found that the urban elderly consumed more protein and fat, both in absolute terms and relative to total energy, than the rural elderly. These differences may have arisen from the fact that city residents generally have higher 
incomes and better supplies of a range of foods than rural people, and can, for example, consume more animal foods. High-quality protein, including that of animal and bean origin, accounted for $>40 \%$ of their total protein intake, but the corresponding figure for the rural elderly was $<25 \%$. The additional foods eaten by city dwellers comprised meat, eggs, milk, fish, bean products and vegetables. The average daily intakes of animal foods were 207.0 and $173.0 \mathrm{~g}$ for men and women respectively. This was almost four times the intakes of rural men and women who consumed only 61.28 and $48.43 \mathrm{~g}$ of animal foods respectively. In rural areas, most people eat foods they have grown themselves. Few foods are purchased from the market, so their diet is more restricted. They have been accustomed to feeding themselves on cereal foods (mainly wheat, rice and corn), which supply $>65 \%$ of total energy. Their subsidiary foods consist mostly of vegetables with small amounts of meat, eggs, fish and bean products. No fresh milk is provided in rural areas and only a few people consume milk powder as a tonic. Another striking difference in food intake was that city dwellers consumed a significantly higher amount of fruit which may contribute to an improved vitamin nutrition. Thus regional differences in food intake were influenced either by tradition or by socioeconomic factors.

The current study shows that mean intakes of energy were equal to or a little above the RDA for both urban and rural groups. Protein intakes of the urban elderly were $>90 \%$ of RDA, which can well meet the needs of the elderly. Fat intakes were markedly above the level of 20-25\% proposed by the Chinese Nutrition Society (1989). Of the micronutrients investigated, none reached the RDA except iron, thiamin, and ascorbic acid in the case of urban groups, and except iron, thiamin, nicotinic acid in the case of rural groups. This strongly suggests that some of these people are deficient in some micronutrients. Similar results were reported from the Beijing study (Xihe, 1988) when our programme was nearly completed. In that study, 433 elderly people aged 60-75 years from both urban and rural areas of Beijing municipality were investigated using diet recall. The results revealed the common picture of inadequate intakes of calcium, retinol and riboflavin in both areas, insufficient intakes of protein in rural areas and over-consumption of fat in urban areas. This food pattern seemed imperfect for the elderly in view of their physiological characteristics. It has been suggested that a prudent diet for the elderly should include adequate protein, vitamins and calcium, but be low in fat, so as to prevent the present high prevalence of nutrition-related diseases such as cardiovascular diseases, cancer and osteomalacia in elderly populations (Ji, 1987). Newly published dietary guidelines once more emphasized the control of fat intake, particularly fat of animal origin, in developed areas of China, so as not to exceed 20-25\% of total energy (The Chinese Nutrition Society, 1990). Our subjects from the urban area had higher fat intakes than recommended, while subjects from the rural area had rather low protein intakes. We would suggest our urban subjects should reduce their consumption of animal foods and particularly of pork, since the pork currently on sale contains $>60 \%$ fat by volume. On the other hand, the rural elderly could allow a moderate increase in their intake of various animal foods and should increase their consumption of fruit. Certainly, this should be a priority in developing their economy.

\section{Anthropometry}

The nutritional status of the urban elderly, as evaluated by the anthropometric indices, was better than that of the rural elderly. Urban groups had generally higher values for all the direct measurements, although blood pressures were not different. However, the rates of overweight plus fat people in the urban groups were significantly higher than those in the rural groups. This difference could be attributed in part to the nutritional factors discussed previously and to the lower energy expenditure of the urban elderly. Their daily activities 
mainly consisted of doing housework, shopping for food, enjoying the arts, caring for children, reading books and engaging in light exercise. In rural areas, most of the men were engaged in farmwork, and expended much more energy than the urban elderly. Housework was also more demanding in rural areas than for city families, because there are fewer labour-saving appliances. In spite of their higher intakes of energy per kg body-weight, it seemed that the energy intakes of rural men were still not enough to balance their expenditure.

Although no significant differences in blood pressure were found, the ratio waist circumference : hip circumference was positively correlated with systolic blood pressure in both men and women. This result was consistent with the 13-year follow-up study of Larsson et al. (1984) which suggested that the distribution of abdominal adipose tissue is probably more predictive than body-weight, of high blood pressure.

Our measurements of height, body-weight and blood pressure were consistent with the results of Weishan (1985). BMI and upper arm circumference were close to, but a little higher than, the values reported by Woo et al. (1988) for Hong Kong elderly Chinese, which are representative of the south China population. No previous study has reported waist circumference, hip circumference and triceps skinfold thickness for the $70+$ age group, so the results reported here could provide reference values for future studies.

\section{REFERENCES}

Academy of Medical Science of China (1983). Tables of food compositions, 3rd ed. Beijing: People's Hygienic Press.

The Chinese Nutrition Society (1989). Recommended Dietary Allowances. Acta Nutrimenta Sinica 11, 93-95.

The Chinese Nutrition Society (1990). Diet Guidelines for Chinese. Acta Nutrimenta Sinica 12, 10-12.

Huide, H. (1985). Distribution of elderly Chinese aged 60 years and over. In Atlas of the Elderly Population of the People's Republic of China, pp. 11. Beijing: Map Publishing House.

$\mathrm{Ji}, \mathrm{Z}$. (1987). The importance of elders' nutrition and the physiological characteristics and special nutrition requirements of aged people. Acta Nutrimenta Sinica 9, 81-83.

Larsson, B., Svardsudd, K., Welin, L., Wilhelmsen, L., Bjorntorp, P. \& Tibblin, G. (1984). Abdominal adipose tissue distribution, obesity and risk of cardiovascular diseases and death: 13-year follow up of participants in the study of men born in 1913. Clinical Research 288, 1401-1404.

Manchang, X. \& Xinsu, Z. (1987). Nutritional survey of the aged. Acta Nutrimenta Sinica 9, 296-299.

Weifu, P. (1984). Dietary study on institutionalized elderly of Guangzhou city. Journal of Chinese Geratology 2 , 34.35 .

Weishan, L. (1985). Studies on five physiological parameters of the elderly of four provinces and four cities in China. Chinese Journal of Geriatrics 4, 214-222.

Woo, J., Ho, S. C., Donnan, S. D. B. \& Swaminathan, R. (1988), Nutritional status of healthy, active Chinese elderly. British Journal of Nutrition 60, 21-28.

Xianrong, F., Weifu, P., Minglu, H., Ruiyi, Q., Jiwei, Y. \& Yusheng, Z. (1987). A nutritional survey of elderly intellectuals in Guangzhou. Acta Nutrimenta Sinica 9, 60-64.

Xihe, Z. (1988). Dietary study of the middle-aged and elderly populations. In Collection of the Fifth Conference of The Chinese Nutrition Society, pp. 89-90. 